\title{
EVOLUÇÃO DA DOUTRINA ÉTICO-MORAL AGOSTINIANA EM RELAÇÃO À SEXUALIDADE
}

Marcos Roberto Nunes Costa*

SÍNTESE - A evolução da doutrina ético-sexual de Agostinho se encontra na polêmica com os maniqueus e os pelagianos, especificamente quando trata da questão do matrimônio. Agostinho defende o matrimônio como um bem ontológico, fundamentado em três finalidades: procriação, fidelidade e indissolubilidade. Em relação ao primeiro item, o pensamento de Agostinho assume, progressivamente, quatro posiçōes, que serão descritas neste estudo. Em relação aos dois últimos itens, năo houve evoluçāo no pensamento de pensamento: ele não admite a quebra da fidelidade e/ou da indissolubilidade do matrimônio.

PALAVRAS-CHAVE - Ética de Agostinho. Ética sexual. Concepção de matrimônio. Objetivos do matrimônio. Sexo, matrimônio e pecado. Evolução do pensamento de Agostinho sobre ética sexual.
ABSTRACT - The evolution of the sexual-ethical doctrine of Augustine can be found in his polemics with the Manicheas and Pelagians, specifically when he treats the issue of the matrimony. Augustine defends the matrimony as an ontological Good, grounded on three finalities: procreation, fidelity and indissolubility. About the first item, Augustine comes to assume four different positions, showing a development in his thought. In relation to the last two items, there was no evolution in his thought: he does not accept the breaking of fidelity and/or of the indissolubility of matrimony.

KEY -WORDS - Augustine's ethical theory. Sexual ethics. Conception of matrimony. Aims of matrimony. Sex. Matrimony and sin. Evolution of Augustine's thought on sexual ethics.

\section{Introdução}

Nos últimos tempos, especialmente a partir do florescimento dos movimentos feministas, pelo mundo afora, é comum encontrarmos as mais severas críticas ao comportamento ético-moral, assumido pela Igreja Católica, ao longo dos séculos, em relação à mulher, ao sexo e ao matrimônio. E dentre os principais protagonistas responsáveis por uma suposta visão "desastrosa" da sexualidade no seio do Cristianismo, aponta-se Santo Agostinho, conforme palavras da teóloga feminista alemã Uta Ranke-Heimemann: "O homem que fundiu o cristianismo com o ódio ao sexo e ao prazer numa unidade sistemática foi o maior dos Padres da Igreja, Santo Agostinho"1.

* Professor do INSAF. Professor e coordenador do Grupo de Estudo em Ética e Política na Idade Média - Departamento de Filosofia da UNICAP.

1 Ranke-Heinemann, 1996, p. 88.

\begin{tabular}{|l|l|l|l|l|l|}
\hline VERITAS & Porto Alegre & v. 48 & n. 3 & Setembro 2003 & p. 375-390 \\
\hline
\end{tabular}


A partir dessa e outras militantes feministas, bem como de meros simpatizantes do Feminismo de ambos os sexos, podemos dizer - seguindo as pegadas do renomado agostinólogo italiano, Agostino Trapè - "que está na moda atualmente falar mal sobre esse ponto - e não só sobre esse - do bispo de Hipona"2.

Dentro dessa perspectiva feminista, defende-se que não há, em Santo Agostinho, uma visão ético-moral, em defesa da dignidade da mulher, do sexo e do matrimônio. Antes, pelo contrário, que, no tocando a isso, seu pensamento é, totalmente, antiético ou, pelo menos, que não corresponde ao verdadeiro espírito ético cristão.

A partir de tais críticas, resolvemos nos debruçar sobre as Obras literárias do próprio Bispo de Hipona e de comentadores seus, a fim de investigarmos se tais críticas têm, realmente, sentido ou até onde condizem, ou não, com o genuíno pensamento agostiniano.

\section{Em defesa da dignidade do sexo e do matrimônio: contra os maniqueus}

A doutrina ético-moral de Agostinho acerca da sexualidade, começa, ou enquadra-se, num primeiro momento, dentro da sua polêmica maior com os maniqueus, na qual refuta-os, não obstante, tenha sido acusado, mais tarde, na polêmica pelagiana, e ainda hoje, de permanecer maniqueu, pelo resto da vida e, por conta disso, de ter uma visão negativa do sexo, da mulher e do matrimônio, conforme diz, criticando os acusadores, Agostino Trapè:

Diz-se que por causa da sua adesão ao maniqueísmo, o qual, ainda depois da conversão,

the teria deixado não poucas escórias, a sua doutrina sobre o matrimônio teria assumido tintas foscas e pessimistas, da qual a dignidade da mulher sairia gravemente afetada ${ }^{3}$.

Portanto, é na polêmica antimaniquéia, que vamos encontrar os primeiros vestígios da concepção ético-moral de Agostinho, acerca da sexualidade, a que será seguida da disputa antipelagiana, na qual assume a sua expressão máxima.

Como é do conhecimento de todos, durante cerca de nove anos, Agostinho foi maniqueu, cuja moral geral estava assentada em três mandamentos, chamados no Maniqueísmo, de marcas ou selos ("signacula"), a saber: o selo da boca, das mãos e dos seios.

No que diz respeito à sexualidade, nosso objeto de estudo aqui, pelo último selo, dos seios (signaculum sinus) ${ }^{4}$, o maniqueu submetia-se a uma rigorosa renúncia a todos os prazeres sexuais, visto ser, a libido ou concupiscência, o pior de todos os males para os maniqueus, conforme explica Puech:

2 Cf. Trapè, 1976, p. 227.

3 Ibid., p. 227. A tese de que o ascetismo maniqueísmo deixaria marcas negativas, na visão agostiniana de sexualidade é defendida, também, com grande insistência por Ranke-Heinemann, 1996, p. 92-93.

4 Para refutar a moral ascética decorrente do selo dos seios dos maniqueus, Agostinho dedica o capítulo XVIII, do Livro II, do Sobre os costumes da Igreja católica e os costumes dos maniqueus. Bem como os capítulos 21 e 22 do Contra Secundino maniqueu, o Contra Félix maniqueu, I, 7-8 e o Livro VI do Contra Fausto maniqueu. 
Uma vez que a 'concupiscência', a libido, é a expressão extrema e mais temível da matéria, desta nasce o pecado capital: a fornicação. E quem aspira em recuperar a pureza do seu ser ou a manter-se nesta deve em primeiro lugar fugir das tentaçōes e os gozos carnais ${ }^{5}$.

Os maniqueus acreditavam que, através do sexo, propagar-se-ia a condenação das centelhas da luz (o Bem) na matéria. Por conta disto, para os "eleitos" ou religiosos, recomendavam uma condenação radical à procriação ou geração de toda e qualquer espécie, inclusive do próprio homem. Ou seja, aos "eleitos", não era permitido se casar e procriar, uma vez que isto significava a reprodução de almas contaminadas e presas à matéria ou o retardamento da libertação definitiva das partículas luminosas, encarceradas nos corpos vivos ${ }^{6}$.

Já aos "auditores" ou simples catecúmenos, a cuja classe pertencia Agostinho, por não fazerem parte da hierarquia, ou não terem alcançado ainda o grau da perfeição, era permitido casar e ter filhos, conforme diz Puech:

Tais preceitos eram obrigatórios para as classes hierárquicas, já os auditores eram livres

para fazer atividades profanas: para possuir, edificar, semear, colher, ser agricultor, artesão ou comerciante, casar-se ou viver com uma concubina e ter filhos?

Mais tarde, convertido ao Cristianismo, Agostinho não, apenas, superaria o Maniqueísmo mas, contra estes, defenderia a dignidade do sexo, da mulher e do Matrimônio, conforme veremos.

\subsection{0 matrimônio, um bem ontológico}

Em primeiro lugar, como princípio fundante, Agostinho defende ser a união, entre homens e mulheres, uma tendência natural, ontológica, querida por Deus, desde 0 início da humanidade e tomada pela natureza mesma, essencialmente, social do homem, cujo fundamento último não está só na procriação, mas, também, e talvez o mais importante, no amor ou amizade entre os sexos opostos.

Para tal, em o Sobre os Bens Conjugais, começa dizendo:

A natureza humana é sociável ${ }^{8}$ e encerra em si um bem excelente e natural, que força à amizade. Assim, quis Deus que todos os homens procedessem de um só, a fim de que na sua

5 Puech, 1995, p. 63.

6 Messina, 1954, p. 298: "Devemo-nos abster da geração; porque esta constituí, aos olhos dos maniqueus, o meio propício para multiplicar a matéria e promulgar, portanto, a prisão das substâncias da luz". Cf. Vannini, 1989, p. 22: "A geraçāo humana, a procriação, são, poł̀isso, vistas pelo Maniqueísmo como o pecado por excelência. No momento em que cada criança vem ao mundo, prolonga-se a prisão de um determinado número de partículas da luz, concentradas no esperma". Igualmente, Puech, 1995, p. 63: "Os atos sexuais produzem, como resultado, a propagaçäo da espécie, a transmissão do Mal original [...]. Em suma, a sexualidade constitui o mais grave obstáculo à redençảo da humanidade, a que essa retarda ou impede".

7 Puech, 1990, p. 446. Ver, também, Agostinho em o Contra Fausto maniqueu: "Assim vossos ouvintes têm mulheres e filhos, reúnem ou conservam para si patrimônio, comem carne, bebem vinho, se banham em público, colhem uvas, fazem negócios, exercem cargos públicos e, sem embargo, consideraisvos entre os vossos e não entre os gentios" (Contra Faust. man., XX, 23).

8 Igualmente no Sobre a Cidade de Deus, ao defender a paz. como o maior de todos os bens almejados neste mundo, diz que "nenhum animal é mais feroz por vício, nem mais social por natureza que 0 homem"(De civ. Dei, XII, 27). 
sociedade estivessem unidos entre si, não só pela semelhança da natureza, mas pelos laços de parentesco. A primeira sociedade foi constituída por um homem e uma mulher. Deus não os criou separadamente, unindo-os depois como dois estranhos. Do homem tirou a mulher, manifestando assim a força da união no lado, do qual foi extraída e formada a muther. Pelos lados se unem dois que caminham juntos, e se dirigem ao mesmo ponto (De bono coniug., I, 1).

Sendo a união entre homens e mulheres uma tendência natural, Agostinho passa, então, a defender a institucionalização do casamento como um Bem ontológico, o qual está assentado, no famoso tripé de finalidades: a prole, a fidelidade e o sacramento ou indissolubilidade.

\subsubsection{A procriação, no casamento}

Quanto ao primeiro item do tripé, a prole, tentando refutar os maniqueus, que condenavam, totalmente a procriação e, conseqüentemente, o sexo, Agostinho assumiria progressivamente as seguintes posiçōes:

Num primeiro momento, no período do Agostinho recém-convertido ou nas primeiras obras antimaniquéias, o Sobre o Gêneses Contra os Maniqueus, por exemplo, tentando defender a santidade da união entre homens e mulheres, interpreta o versículo bíblico do "cresceis e multiplicai-vos" de forma espiritual, como uma união conjugal espiritual. Para tal, buscando excluir, da procriação, toda e qualquer possibilidade de pecado, lança a hipótese de que, antes do pecado original, no estado primitivo de inocência, haveria a procriação sem o sexo ${ }^{9}$. Só a partir do pecado original passaria, então, a existir uma relação estreita (negativa) entre procriação, sexo e pecado. Até então, a procriação estaria totalmente isenta do sexo e, conseqüentemente, do pecado.

Entretanto, tempos depois, no Agostinho da meia-idade, tendo sido acusado, pelos pelagiano ${ }^{10}$, de permanecer maniqueu, por fazer uma associação direta entre procriação, sexo e pecado, ele passaria, no Sobre o Gêneses ao Pé da Letra, a uma segunda postura, desta feita, mais positiva, da relação entre procriação e sexo, chegando, agora, a admitir que, mesmo no Paraíso, Adão e Eva mantiveram relações sexuais, "embora sem prazer" (De gen. ad litt., II, 21) ou seja,

no Éden nem o ato sexual teria acontecido sem o ardor desordenado da concupiscência: os genitais masculinos teriam seminado como os agricultores seminam nos campos, com a exclusão de qualquer prazer libidinoso e a procriação teria ocorrido, sem a fadiga e a dor do parto (Idem, IX, 3.6).

É o chamado sexo ideal, sem pecado.

9 Cf. De gen. contra man., I, 19, no qual conclui que, no Paraíso, a ligação entre o homem e a mulher era assexuada.

10 Aqui, Brucculeri, 1945, p. 157, chama a atenção para o fato de que "Santo Agostinho defende o matrimônio nāo só contra os ataques dos Maniqueus, mas, além disso, contra os opostos erros dos Pelagianos". Por isso, o referido autor, mas não só ele, defende a tese de que, no que se refere à sexualidade, a posição de Agostinho encontra-se entre o Maniqueísmo e o Pelagianismo. 
Suprimida a relação direta entre sexo e pecado, o sexo passa a ser condição da procriação e esta, conseqüentemente, (através do sexo) uma das principais finalidades do matrimônio ${ }^{11}$. Conforme diz, mais tarde, em o Sobre a Cidade de Deus:

Nós, ao contrário, sustentamos firmemente que o cresceis e multiplicais e o encheis a terra é, segundo a divina bênção, um dom do matrimônio, instituído por Deus no princípio, antes do pecado, quando os criou macho e fêmea: evidentemente o sexo está na came... Parece (portanto) claramente que Deus os criou macho e fêmea, com corpos de sexos diversos, para gerarem filhos, e deste modo crescer e multiplicar e encher a terra: negá-lo seria uma verdadeira absurdidade (De civ. Dei, XIV, 22) ${ }^{12}$.

Ou seja, tendo, como finalidade a procriação, o sexo deixa de ser um pecado, tornando-se um bem necessário, conforme palavras de Antonio Pieretti:

Se a prole é um bem, também o uso do matrimônio para tal objeto é um bem. E neste caso a concupiscência camal, que por si mesma não é um bem, responde a uma finalidade moralmente honesta na ordem hierárquica do universo. Pois, como tal é usada para um fim bom $^{13}$.

A partir deste momento, o que Agostinho prega não é a exclusão total do sexo, mas o "sexo ordenado", controlado pela vontade, livre das paixões ou prazeres desordenados. O sexo voltado unicamente para procriação, a começar, pelo praticado por Adão e Eva, no Paraíso ${ }^{14}$. É o que defende, por exemplo, no Sobre a Cidade de Deus, quando responde ao suposto questionamento anterior, no Sobre o Gênesis ao Pé da Letra, de que "antes da queda os homens pudessem controlar os órgãos sexuais como são capazes de controlar outros membros"(De gen. ad litt., IX, 10):

Movemos as mãos e os pés para que estes realizem suas funçōes especiais, quando assim queremos; isso não envolve relutância por sua parte, e os movimentos são realizados com toda a facilidade [...]. Então por que não devemos acreditar que os órgăos sexuais pudessem ter sido servos obedientes da humanidade, ao comando da vontade, da mesma forma que os outros ...? (De civ. Dei, XIV, 23).

11 Pieretti, 1996, p. 39, comentando a na doutrina ético-moral-sexual de Agostinho, chama a atenção de que, daqui para frente, "é na procriação dos filhos que a união conjugal do homem com a mulher encontra a sua plena justificaçāo".

12 Brown, 1990, p. 329, chama a tençāo de que "a partir de aproximadamente 400 até o fim de seus dias, Agostinho escreveu invariavelmente sobre Adão e Eva como seres humanos físicos, dotados dos mesmos corpos e características sexuais que nós". Mas do que isto, "colocados no Paraíso para fundar um populus; e fundar um populus implicava mais do que a uniāo desincorpórea de almas semelhantes".

13 Pieretti, 1996, p. 52. E o próprio Agostinho, em o Sobre os Bens Conjugais, insiste na idéia do sexo, no casamento, como não pecado: "O ato conjugal em ordem à geração, não é pecado; para acalmar a concupiscência em virtude da fidelidade conjugal e sempre com o cônjuge, năo passa de pecado venial. A fornicação e o adultério, sempre sảo pecado mortal" (De bono coniug., VI, 6). Cf. também, idem, VII, 6; VIII, 8; X, 11; XVIII, 21.

14 Neste período, como conseqüência do sexo exclusivamente para procriação, Agostinho combate duramente a contracepção, como, por exemplo, no Sobre as Relaçōes Adulterinas, II, 12: "É condenável e vergonhoso praticar o coito com a própria esposa e ao mesmo tempo impedir a concepçẫo de filhos. Foi o que fez Onā, filho de Judá, e por isso Deus o matou [...]. E noutra obra, o Sobre o Casamento e a Libertinagem, I, 15, completa: "Às vezes essa atrocidade obscena ou essa obscenidade atroz chega ao ponto de as pessoas adquirirem venenos para a infertilidade [...] para que a esposa se transforme na prostituta do marido, ou para que ele cometa adultério com a própria esposa". 
E aqui, apresenta o pecado original, como causa da fragilidade ou deficiência por parte do homem, em näo poder controlar a si mesmo e, conseqüentemente, 0 sexo, ou seja, a concupiscência.

Muito embora, vale salientar, para Agostinho, o pecado original não se constitui ontologicamente na relaçâo ato sexual ou carnal em si, mas, antes, esta é o efeito ou fruto do primeiro pecado, a saber: da desobediência a Deus, por parte do homem, ao que chama de "malum culpae". O segundo pecado, o prazer sexual ou carnal - a concupiscência, aparece, pois, como penalidade (malum poenae) ao primeiro pecado, como uma deficiência ${ }^{15}$. Daí dizer Agostinho que "o castigo pela queda foi primeiro sobre a sexualidade" (De civ. Dei, XIV, 20) ${ }^{16}$.

Portanto, a rigor, a libido ou concupiscência, que caracteriza o pecado sexual, não está, propriamente, no ato carnal ou corporal em si, mas na má intenção da vontade do homem que, não conseguindo controlar a sua própria vontade, também, não consegue controlar o sexo, provocando a desordem, entre o espírito e a carne. Daí, a necessidade de sabermos distinguir entre a faculdade sensitiva, que é um bem, e paixăo desordenada, que, enquanto desordenada, é um mal: a esta chama, com termo bíblico, concupiscência, conforme esclarece o próprio Agostinho:

Uma coisa é a força do sentido, outra coisa a desordem da concupiscência: distingue estas duas coisas com diligência, se năo queres errar gravemente (Contra Jul. opus incomp., IV, 29 $)^{17}$.

Concretamente, a sexualidade é um bem, ao contrário. A paixão sexual ou concupiscência, ao contrário, enquanto provém e resiste à razão, é um mal. "Por isso - diz Agostinho -, assim como não devemos aprovar este mal como causa daquele bem, também não devemos condenar aquele bem como causa deste mal" (De nup. et. concup. I, 1) $)^{18}$.

15 A este respeito diz Agostinho, no Sobre o Livre-Arbitrio: "As más açōes que cometemos, por ignorância, e as boas que não conseguimos praticar, por deficiência, apesar de boa vontade, denominam-se 'pecados', visto terem sua onigem, naquele primeiro pecado cometido, por livre vontade, por Adão: estes não são mais que consequêencia daquele" (De lib. arb., III, 18, 51).

16 E, mais adiante, diz: "Nunca devemos crer que a bênção de Deus, 'crescei e multiplicai-vos e povoai a terra', tenha sido realizada, através do desejo lascivo do casal, colocado no Paraíso. Foi, com efeito, depois do pecado, que surgiu tal desejo sexual (libido)"(De civ. Dei, XIV, 21).

17 E, mais adiante: "Como a sensação da dor é diferente da dor, assim a sensação da came é diferente da concupiscência da carne" (idem, VI, 18). Igualmente no Sobre as Núpcias e a Concupiscência, Agostinho insiste nessa diferença: "Uma coisa é o instinto da geraçāo que é um Dom de deus e outra é a concupiscência da alma que se junta ao sentido e nos conduz indiferentemente ao lícito e ao ilícito, que não pode, como tal, vir de Deus" (De nup. et concup., II, 7).

18 Falando acerca da insistência de Agostinho, em demonstrar que, em si, o corpo (e com ele o sexo) é um bem e que o pecado da concupiscência não está no corpo, mas na alma, que usa mal do corpo, Musuti, 1989, p. 127, diz: "A concupiscência, fruto do orgulho do homem, conduz a um uso incorreto do instrumento corpo por parte da alma, como o carpinteiro que usa mal o martelo [...]. A concupiscência é um sinal evidente do decaimento ontológico da alma, de um estado da alma que possui menos ser". E , mais adiante, completa: "A concupiscência é portanto a incapacidade intrínseca da alma de determinar e gerir a si mesma segundo a sua natureza. O papel do corpo na concupiscência é semelhante àquele da sensação e do objeto: a concupiscência provém da alma...". 
De qualquer forma, nesse momento, Agostinho admite que o prazer sexual, visto como pecado, entrou no mundo pelo pecado original, não como causa, mas como efeito, o que levou Uta Ranke-Heinemann a interpretar, erroneamente, que, para a hierarquia celibatária da Igreja Católica "o locus por excelência do pecado está no sexo - uma póstula baseada nas fantasias de Agostinho, em que manifesta o ódio ao prazer"19.

Também, vale relembrar, conforme vimos, no início deste tópico, embora Agostinho apresente a procriação como legitimação do uso do sexo que, por sua vez, justifica o casamento, entretanto, essa não é a única finalidade do matrimônio. No Sobre os Bens Conjugais, por exemplo, ele apresenta o matrimônio, como um Bem social, independentemente do sexo e da procriação, tendo, como fundamento último, e talvez o mais importante, o amor mútuo (amizade), como está escrito:

A mim me parece que é um Bem, não só pela procriação dos filhos, mas também pelo convivio social de ambos os sexos. Porque se assim não fosse, não poderíamos falar de matrimônio entre idosos, particularmente se já perderam os filhos, ou nunca os tiveram. Ora, num bom matrimônio, mesmo entre idosos, embora tenham murchados os ardores juvenís do homem e da mulher, permanece ainda vigoroso o amor entre o esposo e a esposa" (De bono coniug., I, 3, grifo nosso $)^{20}$.

Por isso, em uma outra Obra, o Sobre a Santa Virgindade, apesar de preferir o celibato ao casamento, ao falar para as virgens consagradas, sente-se, no dever de chamar a atençäo destas dos perigos da tentação de desprezar a dignidade do matrimônio, em favor da continência, quando, na realidade, ele é um bem, um bem menor, mas um bem:

Alerto aqueles e aquelas que professaram continência perpétua e a santa virgindade de preferir esse bem sem julgar as núpcias um mal. Sabemos que o Apóstolo disse sem engano, mas com toda a verdade: quem esposar uma mulher faz bem; quem não esposar faz melhor (1 Cor. 7, 38)... Esta é a doutrina do Senhor e do Apóstolo, a doutrina verdadeira, a doutrina sã: escolher as coisas melhores sem condenar as menores [...]. Quem, portanto - escreve -, quer permanecer sem casar-se, nảo julgue do matrimônio como uma fossa de vícios, senăo que o supere como colina de um monte menor, para ir refugiar-se no monte da perfeita continência (Idem, XVIII, 18).

E, mais do que isso, no Sobre os Bens Conjugais, apesar de confirmar a idéia de que a continência é melhor que o matrimônio, entretanto chega a dizer que é melhor um casamento casto que uma continência ilícita:

... são dois bens o matrimônio e a continência, dos quais o segundo é melhor [...]. Entretanto, do mesmo modo que os ágapes dos justos são melhores que os jejuns dos sacrílegos,

19 Ranke-Heinemann, 1996, p. 103.

20 Igualmente, no Sobre a Santa Virgindade, diz: "Certamente o matrimônio tem os seus bens; não tanto porque gere filhos, mas porque os gera honestamente, legitimamente, castamente, socialmente e, gerando, os educa concordiamente, saudavelmente, constantemente; porque os cônjuges conservam a felicidade mútua; porque nảo violam o sacramento da união" (De sancta virg. XII, 12). Por isso, diz Brucculeri, 1945, p. 163: "Como está claro, o matrimônio para Santo Agostinho é rico de elementos morais, que a esses acrescenta-se o valor social, valor que expressamente celebra o Santo Doutor fazendo do matrimônio um elemento e um viveiro da sociedade". 
assim as núpcias dos fiéis sāo preferiveis à virgindade das ímpias [...]. a fidelidade das casadas é melhor que á infidelidade das virgens [...] as mulheres fiéis se casam para viver castamente com seus maridos, enquanto as virgens ímpias fornicam, traindo o Deus verdadeiro [...]. Vê-se claramente que a virgindade pode dar-se sem a obediência, porque a mulher depois de ter aceito o conselho da virgindade, e permanecendo virgem, pode transgredir ou menosprezar os mandamentos. Conheço muitas virgens consagradas, que são tagarelas, curiosas, ebriosas, rixosas, ávaras, orgulhosas: coisas que são contra os mandamentos, ultrapassando a Eva no pecado de desobediência. Conseqüentemente, nảo só a obediente deve ser preferida à desobediente, mas a casada mais obediente é preferivel a uma virgem menos obediente (De bono coniug., VIII, 8; XXIII, 30).

Já, nas obras da maturidade, Agostinho dá um passo à frente (terceira fase) e se aproxima dos pelagianos, ao admitir não apenas o sexo, mas o prazer no sexo, inclusive chega a admitir que havia prazer nas relaçöes sexuais, ocorridas no $\mathrm{Pa}$ raíso, antes do pecado original, muito embora este "não suprimia o pensamento da mente como prazer avassalador" (Contra Jul. opus incomp., IV, 39) ou "só ocorria com a vontade da alma" (Idem, VI, 22), ou seja, continua o princípio do sexo moderado ou ordenado e só para procriação. Por isso, antes, já havia advertido: "O ato sexual é bom quando ocorre com a intenção correta [ter filhos]. Mas é um pecado quando o casal o submete ao desejo"(Idem, IV, 29).

Pata tal, Agostinho faz uma distinção importante entre "sentir" e "buscar" o prazer. O que deve-se evitar é o segundo. Ou seja, a busca do prazer não deve Ter, como finalidade última, o sexo. A finalidade última deve ser a procriação, o prazer é apenas meio, que deve ser controlado pela vontade, conforme diz no Contra Juliano, obra incompleta: "O que não pode ocorrer sem desejo não deveria, entretanto, ocorrer unicamente por causa dele" (Idem, V, 9). E, mais adiante, completa: "Se houvesse outra forma de se ter filhos [...]. Mas como não há como procriar de outra forma, os casais que fazem sexo com o fim de procriar fazem bom uso desse mal" (Idem, V, 46) ${ }^{21}$. Neste caso, o sexo se constitui num pecado venial, desculpável ou perdoável.

Por fim, temos o último passo (quarto) na visão agostiniana da sexualidade, quando, considerando que o homem é um ser decaído, o qual, por mais que se esforce, pela livre vontade, não consegue conter totalmente os seus desejos carnais (pecado de deficiência, conseqüência do primeiro pecado), em nome de um segundo item do tripé de finalidades do casamento - a fidelidade -, admite o sexo por prazer ou o prazer no sexo, dentro do matrimônio, é claro.

21 Comentado este terceiro momento da concepção agostiniana de sexualidade, BROWN, 1990, p. 331 34, escrever: "No estado original de Adão e Eva, o desejo sexual não estava ausente, mas coincidia perfeitamente com a vontade de consciência; näo introduziria nenhum elemento disruptivo na clara serenidade de seu casamento [...]. Para Adảo e Eva, o prazer sexual e a vontade caminhavam juntos", conclui o autor: "A ânsia de harmonia e de uma obediência serena em todos os níveis [...] foi o que então passou a ocupar o centro do pensamento de Agostinho. Seu ideal eram uma alma humana, um corpo humano e uma sociedade humana năo fendidos pela tenebrosa distorção da vontade decaída" (Idem, p. 335). 
Primeiro, aceita a idéia do sexo com prazer, mantendo-se o princípio da moderação e com vistas à procriação. Segundo, chega a admitir, até, o sexo só por prazer, É o chamado sexo tolerável e perdoável (venial); um mal menor, remédio ou antídoto contra males maiores: o sexo individual (masturbação), o sexo com animais, etc. e, principalmente, o adultério e a fornicação, que são pecados mortais, conforme diz o próprio Agostinho, no Sobre os Bens Conjugais, ao comentar o sexo com a própria esposa, quando está grávida:

Essa exigência imoderada do ato conjugal, que aos esposos o Apóstolo não manda imperiosamente, mas lhes concede indulgentemente: que se unam ainda que não seja por causa da procriação, senão pelos seus depravados instintos, para proteger o matrimônio contra 0 adultério $e$ a fornicação. E não se diga que isto se admite em nome do matrimônio, mas por causa deste se tolera com indulgência [....]. Portanto, não é só com vistas à procriação que a caritas conjugalis encontra expressão; essa se manifesta também quando um dos dois se entrega ao outro para que esse nâo incorra na fornicaçăo, ou não caia em pecado mortal (De bono coniug., $\mathrm{X}, 11)^{22}$.

Claro que tal exceção tem limites ou continua o princípio de uma certa moderação no sexo, por prazer, no matrimônio. É o que aparece, no capítulo seguinte da supracitada obra, quando repreende certas práticas sexuais, a que chama de antinaturais, que rebaixam as esposas a condições de prostitutas e/ou os cônjuges, ao nível dos animais brutos, quando diz:

O uso natural do matrimônio, quando ultrapassa os limites da necessidade, é escusável com a própria esposa, mas pernicioso com uma meretriz; o uso antinatural da esposa é mais execrável que o uso antinatural de uma meretriz [...]. Assim, nos casados, deve ser tolerada a intemperança no uso do que lhe é permitido, para evitar que a libido os arraste ao que the é proibido. Por conseguinte, peca menos se recorrer freqüentemente à esposa, que raríssimamente se deslizar na fornicaçăo. Mas se o marido quer abusar antinaturalmente dos órgãos da mulher, ela é mais nojenta em por conceder em si, do que se permitisse fazer com outra (Idem, XI, 12).

Como se vê, não é o sexo, em si, que Agostinho condena ou não há um "ódio ao sexo e ao prazer", como afirma, simplisticamente, Uta Ranke-Heinemann ${ }^{23}$, mas à luxúria ou lascívia, que é o sexo desordenado (discordiosum malum), movido pelo simples princípio do prazer pelo prazer. Esta - a luxúria -, é chamada de sexo indesculpável ou mortal, incluída na lista dos chamados "sete pecados capitais".

Portanto, não há uma separação radical entre sexo e amor, como acusa, ainda, na mesma página, a supracitada autora, quando diz: "Como muitos outros neuróti-

22 Igualmente diz, no Sobre a Cidade de Deus.: "Tanta importância tem o ordenamento disposto pelo Criador e a regra recebida pela criação, que se alguém ultrapassar a medida nas práticas consentidas ao uso é coisa muito mais tolerável que uma transgressão [...+.]. Por isso o excesso de um cônjuge em uma ação lasciva deve ser tolerado, para que a libido não o leve a uma outra não consentida" (De civ. Dei, XI, 12). E aqui, conseqüentemente, Agostinho progrediria, também, em relação à contracepção, tão condenada por ele nas obras da meia idade. Fato este que não levou em conta Ranke-Heinemann, 1996, p. 97, ao afirmar simplesmente que "ao contrário, portanto, do papa (atual) Agostinho não dividiu a contracepção em duas categorias, a permitida e a proibida: tudo era proibido". 
Cos, ele [Agostinho] separa de forma radical o amor da sexualidade"24. 0 que há é uma separação radical entre sexo e luxúria, devolvendo, ao sexo, a sua verdadeira e divina finalidade ou dignidade: o de perpetuar a espécie humana com amor, honestidade e responsabilidade.

\subsubsection{A fidelidade, dentro e fora do casamento}

Dando continuidade e em consonância com o que foi visto até aqui, percebese que Agostinho apresenta a fidelidade, como um segundo item do tripé das finalidades do matrimônio, muito embora estenda este princípio, também, às relaçōes fora do matrimônio, ou seja, as pré-matrimoniais e entre não casados, conforme veremos.

E tamanha é a importância que Agostinho dá à fidelidade que, apesar de, no Sobre os Bens Conjugais, colocar esta num pé de igualdade com a procriação, quando diz: "A dignidade do matrimônio consiste no procriar honestamente e no tomar fielmente o débito conjugal" (De bono coniug, V, 5), mais tarde, no Contra Juliano, obra incompleta, a eleva à condição de superior àquela, quando, ao comparar 0 matrimônio à fornicação, chega à conclusão de que no adultério também há procriação, mas não fidelidade, conforme está escrito: "O matrimônio não se distingue do adultério pela procriação dos filhos, mas pela fidelidade do leito conjugal" (Contra Jul. opus incomp., I, 65) ${ }^{25}$.

Mais do que isso, de forma aparentemente contraditória com a primeira finalidade - da procriaçāo -, Agostinho chegou a admitir, até, o sexo, unicamente, por prazer (dentro do matrimônio, é claro), como forma de garantir o sagrado ${ }^{26}$ princípio (conforme vimos anteriormente) e a rejeitar o sexo, fora do matrimônio, ainda que seja para fins de procriação e para salvar o próprio matrimônio, como, por exemplo, ao condenar "o gesto daquela mulher que - escreve no Sobre o Sermão da Montanha -, para salvar o marido e com o seu consentimento, se entregou a um outro" (De serm. Dom., I, 16) , o que levou o comentador Antonio Pieretti a dizer que "Agostinho, mais uma vez, em referimento aos bens do matrimônio, coloca a fidelidade antes da procriação"27.

A esse respeito, em o Sobre os Bens Conjugais, são inúmeras as vezes em que Agostinho condena o sexo fora do matrimônio, ainda que para fins de procriação, como por exemplo:

24 Ibid., p. 88.

25 Igualmente no Sobre os Bens Conjugais, Agostinho diz que "a fidelidade, além de bem do matrimô. nio, é uma condição tão indispensável para a sua existência que os cônjuges não podem subtrair nem mesmo para satisfazer o desejo de ter uma descendência", ou seja, para ter filhos fora do casamento, em caso de infertilidade por parte de um dos conjugues.

26 Agostinho dá tanta importância à fidelidade conjugal que, em o Sobre os Bens Conjugais, chega a colocá-la como um bem superior à saúde física: "... assim a fidelidade, que é um bem excelente da alma, ainda tratando-se de coisas corpóreas e banais, porquanto deve ser preferida mesmo à saúde corporal, tăo necessária para a nossa vida" (De bono coniug. I, 4).

27 Pieretti, 1996, nota 184, p. 55. 
O que é o alimento para a saúde do homem, é o ato carnal para a saúde do gênero humano [...]. Entretanto, tão desvairado é querer conservar a vida com alimentos nocivos, como procurar a prole por meio de uniōes fornicárias ou adulterinas [...]. Assim como é preferível morrer de fome, antes que comer das viandas consagradas aos ídolos; assim é melhor morrer sem filhos, antes que procurá-los com uniōes ilícitas (De bono coniug., XVI, 18$)^{28}$.

$\mathrm{E}$, aqui, a fim de que se mantenha a fidelidade, ou, como se diz na linguagem do senso comum, "para que um dos parceiros não vá procurar o sexo fora do casamento", Agostinho chega a falar de uma certa "obrigação conjugal" ou "sexo a pedido". Ou seja, quando um dos parceiros, não se contendo, procura o outro que, por sua vez, não está sentindo nenhum desejo. Nesse caso, diz Agostinho, os parceiros têm obrigação de não se negarem um ao outro, para que ele ou ela não incida em num pecado maior, da infidelidade. É o que nos diz, no Sobre os Bens Conjugais:

Os esposos devem a si mesmos uma servidão mútua, não somente na fidelidade da união dos sexos em ordem à procriação, que é o fim primordial desta sociedade do gênero humano nesta vida mortal, mas também por condescender com a fraqueza de ambos e evitar uniões ilícitas. De tal modo que se um dos cônjuges quiser guardar perpétua continência, não possa fazer sem o consentimento do outro [...]. Igualmente, que não se neguem um ao outro aquilo que é conducente, não só para a procriação, senão também para prover à fragilidade e à incontinência, quer o exija o marido da mulher, quer a mulher o exija do marido: não venha a acontecer que, por causa disto caiam em pecaminosas corruptelas... (De bono coniug., $\mathrm{VI}, 6)$.

Como se vê, outro dado interessante é que, apesar das inúmeras vezes em que Agostinho, em seus escritos, fala da submissão da mulher em relação ao homem ${ }^{29}$, entretanto quando chega à questão da castidade e fidelidade conjugal há uma tenaz defesa da perfeita paridade de direitos e deveres, entre ambos, em relação à castidade matrimonial, fora e dentro do casamento.

Para tanto, apoiando-se nas palavras do Apóstolo que disse: " $A$ mulher não tem poder sobre o seu corpo, mas sim o marido; e o marido não tem poder sobre o seu corpo, mas sim a mulher" (1 Cor. 7,4), quando fala deste assunto usa, sempre, o plural ou menciona, explicitamente, ambos os sexos e nunca usa a palavra "ho-

28 Mais adiante, diz: "Unir-se à concubina para ter filhos é maior pecado que unir-se à esposa para satisfazer simplesmente a incontinência" (Idem, XIV).

29 Não iremos apresentar, aqui, os argumentos filosófico/teológicos, adotados por Agostinho, para justificar a submissão da mulher, em relaçăo ao homem, mas tăo-somente registrar o fato de que, por diversas vezes, defende, implícita ou explicitamente, esta tese, como, por exemplo, no Sobre os Bens Conjugais: "Ainda sem a uniāo carnal, poderia dar-se, entre os dois sexos, uma união amical e fraterna, na qual o homem fosse o dirigente e a mulher obsequiosa e obediente". De qualquer forma antecipamos que, neste caso, a mulher não aparece inferior ao homem, por natureza, como fizera, por exemplo, Aristóteles, pois, nesse sentido, para Agostinho, ela é igual ao homem, uma vez que, pela alma, é a imagem e semelhança de Deus, tanto quanto o homem. Admite, sim, que a mulher se encontra condicionalmente submissa ao homem, depois do pecado original, uma espécie de "deficiência" ou "debilidade", fruto do seu pecado primeiro - do orgulho ou soberba, conforme insiste Almeida, 2002, especialmente, no tópico "O Pecado e a Danação de Eva", p. 410-420. Tal assunto será objeto de estudo de um outro artigo a ser elaborado e apresentado, por nós, em outra ocasiảo. 
mem", ainda que em sentido genérico. Por exemplo, no Sobre os Bens Conjugais, ao advertir sobre o prazer sexual no casamento, para que aconteça moderadamente, ao que chama de castidade conjugal, e não de forma desenfreada, a que chama de "adultério no próprio casamento", diz:

Mesmo quando os cônjuges realizam os deveres da uniäo conjugal, embora neste ato procedam com alguma maior incontinência e intemperança, se deve mútua fidelidade [...]. A violaçăo desta fidelidade chama-se adultério, quando arrastados pela própria concupiscência, ou por ceder à concupiscência alheia, se juntam com outro, ou com outra contra o pacto nupcial ... (De bono coniug. I, 4 - grifo nosso) ${ }^{30}$.

Bem como, embora colocando a continência como um bem superior ao matrimônio, conforme veremos mais adiante, mesmo assim, para que a mesma aconteça, dentro do matrimônio, é necessário que haja o consentimento de ambos os cônjuges; um não pode aderir à castidade, sem o consentimento do outro, conforme diz Agostinho:

Também a perpétua continência não pode ser obtida, sem o consentimento do outro. E qualquer um que haja com precipitação, no assumir tal empenho, é seu dever corrigir a temeridade antes que manter a promessa, já que, em tal caso, opera contra a ordem natural, oferecendo o que lhe é próprio, mas usurpando de que não pode dispor a seu bem prazer (De bono coniug., VI, 6).

Não só em relação ao casamento, mas nas relações pré-matrimoniais e fora do matrimônio, deve haver uma total igualdade dos dois sexos, em ordem dos deveres da castidade, conforme conclama em Sermão:

Os rapazes - diz insistentemente o santo Doutor - devem se conservar puros como querem encontrar puras as futuras esposas: os maridos devem observar a mesma fidelidade conjugal que exigem da sua esposa (Serm. 9, 11-12).

Igualmente, depois do fazer uma distinção entre o Direito Civil, que punia severamente 0 adultério da mulher e, menos gravemente, 0 do homem, e o Direito Divino ou dos Céus, que julga homens e mulher, em pé de igualdade, alerta para que os homens não se usem do Direito Civil como uma desculpa para trair suas esposas:

Năo digam: nós somos homens! Nem se apele à Lei Civil [...]; um é o direito de foro, outro o direito do céu. Certas coisas, de fato, se possam fazer iure fori, mas não iure caeli (Serm. $153,6)^{31}$.

30 Nào aqui, mas em outros momentos do Sobre os Bens Conjugais, Agostinho defende a igualdade de direitos e deveres, entre homens e mulheres, como: "O matrimônio entre o homem e a mulher é um bem, tão encarecido e recomendado pela Sagrada Escritura, que nem à mulher repudiada pelo marido the é lícito unir-se a outro, em vida do marido, nem ao marido repudiado pela mulher, lhe é lícito tomar outra até a morte da mulher, que o abandonou" (De bono coniug., III, 3). "Os esposos devem, a si mesmo, uma servidão mútua, não somente na fidelidade da união dos sexos, em ordem à procriação, que é o fim primordial desta sociedade do gênero humano, nesta vida mortal, mas, também, por condescender com a fraqueza de ambos e evitar unióes ilícitas. De tal modo que se um dos cônjuges quiser guardar perpétua continência, nāo o possa fazer sem o consentimento do outro" (Idem, VI, 6).

31 Em apêndice ao Sobre os Bens Conjugais, dividido em dois capítulos intitulados respectivamente, "Repreensāo ao Adúlteros" e "O Crime dos Fornicadores", tece severas críticas aos homens que, por se sentirem superiores às mulheres, se dão ao direito de trairem suas esposas. E, conseqüentemente, faz grandes elogios às mulheres por suportarem as desventuras dos homens. 
Na mesma linha de raciocínio, Agostinho condena também a exploração sexual do homem sobre a mulher, em relaçōes fora do casamento, ou seja, entre näo casados. Para tanto, baseado no preceito que diz: "não faças a outrem, o que para ti não queiras", conclama:

Se alguma vez intentas realizar algum ato lascivo, não queiras justificar-te dizendo: não tenho mulher, faço o que eu quero, pois não peco, às costas da minha mulher [...]. Também näo me digas, descaradamente: me acerco a uma fornicadora, me dirijo a uma meretriz, vou a uma prostituta ou uma mulher pública e não violo o preceito que manda 'näo cobiçar a muIher do próximo'. Não esqueça que os Dez Mandamentos se reduzem a dois que já conhecemos: amar a Deus e ao próximo; e estes dois se reduzem a um só que manda que 'não faças a outrem, o que para ti não queres'(De bono coniug. Apêndice).

Portanto, como se vê, não há um desrespeito deliberado ou despreocupação para com a dignidade da mulher, nem separação entre sexualidade e amor, como afirma simploriamente Leonardo Boff, na orelha do supracitado livro de Uta RankeHeinemman:

A doutrina tradicional concernente à sexualidade faz uma separação brutal entre sexualidade e amor. Os celibatánios que formularam as doutrinas, especialmente Santo Agostinho e Santo Afonso de Ligório, não mostram a menor idéia de dignidade da mulher e da espiritualidade que se realiza entre esposos que se $\mathrm{amam}^{32}$.

\subsubsection{O sacramento ou indissolubilidade do casamento}

O terceiro item do tripé de finalidades do matrimônio é representado, pelo sacramento, o qual deve garantir a indissolubilidade do mesmo.

Para tal, Agostinho usa de dois argumentos ou fundamentos que justificam o matrimônio, como uma instituição indissolúvel: o primeiro - ontológico social/natural, conforme apresentamos, no início deste Trabalho, o matrimônio aparece como uma tendência natural de todo ser humano.

Quanto ao segundo - o teológico/escatológico, Agostinho diz que o matrimônio tem uma função catequético-moral, enquanto instrumento de propagação e regeneração do homem com vista à vida eterna. Para isso, ele deve ser legítimo, casto e honesto, para que os filhos que dele nasçam, possam, pelo bom exemplo dos pais ser educados retamente, e, com isto, alcançar a beatitude. Por isso diz Agostinho:

Esta deve ser a intenção dos bons cônjuges: que a geração seja uma preparação à regeneração do pecado original [...]. Por isso além de procriá-los [os filhos] honestamente, devem acolher os filhos com amor [...]. Educá-los com a pia solicitude e instruí-los na salvação de Deus (Contra Jul., IV, 1; De gen. ad litt., IX, 7; Serm., 349, 7).

Aqui, além da idéia do matrimônio, como um Bem ontológico, enquanto Instituição social querida, criada e abençoada por Deus, ele acrescenta um componente moral e espiritual que transcende à tendência natural e à vontade do homem, tornando a ligação entre homens e mulheres uma instituição sagrada e, portanto,

32 Ranke-Heinemann, 1996, Orelha (De Leonardo Boff). 
indissolúvel. E tal caráter está representado na celebração do Sacramento do matrimônio, cuja importância é tal que, a exemplo do princípio da fidelidade, chega a se confundir um com o próprio matrimônio.

É indiscutível que, tamanha é a importância adquirida pelo Sacramento em Agostinho, que ele não admite a dissolubilidade do matrimônio seja por idade avançada dos esposos ${ }^{33}$, por escolha de voto de continência, por parte de um dos espo$\operatorname{sos}^{34}$, por separação de $\operatorname{corpos}^{35}$ e até mesmo, contrariando o princípio da procriação, por esterilidade de um dos esposos ${ }^{36}$. Em qualquer um desses casos, se um dos esposos contrair segundo matrimônio, com o esposo ou esposa, ainda, em vida, Agostinho chama de adultério. $O$ único caso permitido é por morte de um dos cônjuges ${ }^{37}$. Com isto, Agostinho fecha o tripé das finalidades do casamento, tão bem resumidas numa passagem do Sobre a Santa Virgindade, que diz:

Por certo, o casamento apresenta seus bens próprios que consistem não só na procriação de filhos, mas também por havê-los gerado honestamente, licitamente, casta e socialmente. Uma vez nascidos, os pais educam os filhos com toda solicitude e empenho. E os esposos guardam mutuamente a fidelidade conjugal, sem profanar o sacramento do matrimônio, pelo qual se uniram(De sancta virg. XII, 12).

\section{Referências}

AGostinHO, Santo. A virgindade consagrada. Trad. de Nair de Assis Oliveira. São Paulo: Paulinas, 1990. $201 \mathrm{p}$.

[s.d.]. $37 \mathrm{p}$.

Dos bens do matrimônio. Trad. de Vicente Rabanal. São Paulo: Padres Agostinianos,

. O sermão da montanha. Trad. e notas de Nair de Assis Oliveira. Săo Paulo: Paulinas, 1992. $207 \mathrm{p}$.

. A Cidade de Deus: contra os pagãos. 3. ed. Trad. de Oscar Paes Leme. Petrópolis:

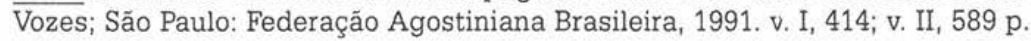

33 Cf. De nup. et concup,. I, 17; De bono coniug., III, 3.

34 Cf. idem, I, 17, 19.

35 Cf. De bono coniug., VII, 6: "De tal força é o vínculo do matrimônio nupcial, que nem pela separação se rompe, já que em vida do marido que a deixou, comete adultério se se casar com outro: e a causa desse pecado é o marido que a deixou". E, mais adiante: "Nem pelo divórcio fica abolida a aliança nupcial, de tal modo que, mesmo separados, sempre serão cônjuges entre si, e cometeram adultério com aqueles a quem se unam depois de casados, faltando ela à fidelidade ao marido e ele à fidelidade para com sua mulher" (Idem, VII, 7).

36 Cf. De bono coniug., VII, 7: "Tăo forte é o vínculo social dos cônjuges, que, uma vez realizado por causa da procriação, não pode ser dissolvido nem por causa da procriação. Porque, neste caso, poderia o homem abandonar a mulher estéril e casar-se com outra que lhe dê filhos. Mas isto não é lícito". E mais adiante: "Permanece o vínculo nupcial, ainda que a prole, por cuja causa foi realizado, não tenha aparecido por causa de manifesta esterilidade, de tal modo que os cônjuges, embora convencidos da impossibilidade de ter filhos, não podem separar-se e unir-se a outros para procurar descendência" (Idem, XV, 17); cf. também, idem, XVI, 18 e De nup. et concup., I, 17,19.

37 Cf. De bono coniug., XV, 17: "Uma vez contraido o matrimônio na Cidade de nosso Deus, que é a Igreja, da qual o matrimônio, proveniente da primeira união do homem e da mulher, recebe um caráter sacramental, não pode ser dissolvido, senão pela morte de um dos conjugues". 

1997. $296 \mathrm{p}$.

O livre-arbitrio. Trad., intr. e notas de Nair de Assis Oliveira. Săo Paulo: Paulus,

AGUSTíN, San. Actas del Debate con Felix. In: Obras completas de San Agustín. Trad., intr. y notas de Pio de Luis. Ed. bilingüe. Madrid: La Editorial Catolica/BAC, 1986. v. XXX, p. 461-542.

Resposta a Secundino. In: Obras completas de san Agustín. Trad., intr. y notas de

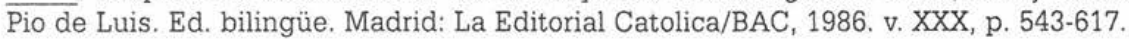

Contra Fausto. In: Obras completas de san Agustín. Trad., int. y notas de Pio de Luis. ed. Bilingüe. Madrid: La Editorial Catolica/BAC, 1993. vol. XXXI, 834 p.

De las costumbres de la Iglesia Catolica y de las costumbres de los Maniqueos. In: Obras completas de San Agustín. Trad. intr. y notas de Teófilo Prieto. Ed. bilingüe. Madrid: La Editorial Catolica/BAC, 1948. v. IV, p. 235-451.

Del Genesis contra los Maniqueos. In: Obras completas de san Agustín. Trad., intr. y notas de Balbino Martin. Ed. bilingüe. Madrid: La Editorial Catolica/BAC, 1957. v. XV, p. 351-498.

Del Genesis a la Letra. In: Obras completas de San Agustín. Trad., intr. y notas de Balbino Martin. Ed. bilingüe. Madrid: La Editorial Catolica/BAC, 1957. v. XV, p. 567-1271.

Réplica a Juliano, obra inacabada. In: Obras completas de San Agustín. Trad., intr. e notas de Luis Arias. Ed. bilingüe. Madrid: La Editorial Catolica/BAC, 1985. v. XXXVI, $639 \mathrm{p}$.

El Matrimonio y la Cuncupiscencia. In: Obras completas de San Agustín. Trad., intr. e notas de Luis Arias. Ed. bilingüe. Madrid: La Editorial Catolica/BAC, 1984. v. XXXV, p. 245-388.

ALMEIDA, Suely Creuza Cordeiro de. Adão no feminino: ou as idéias sobre seu avesso. In: BRANDĀO, Silvana. História das religiöes no Brasil. Recife: Editora da UFPE, 2002. p. 391-421.

BROWN, Peter. Agostinho: sexualidade e sociedade. In: Corpo e sociedade: o homem, a mulher e a renúncia sexual no início do cristianismo. Trad. de Vera Ribeiro. Rio de Janeiro: Jorge Zahar, 1990. p. 318-351.

BRUCCULERI, A. Il pensiero socialle di S. Agostino. Roma: Edizione Cività Cattolica, 1945. $404 \mathrm{p}$.

COSTA, Marcos Roberto Nunes. Santo Agostinho: um gênio intelectual a serviço da fé. Porto Alegre: ADIPUCRS, 1999. 215 p.

O problema do mal na polêmica antimaniquéia de santo Agostinho. Porto Alegre: EDIPUCRS; Recife: UNICAP, 2002. 429 p.

MASUTTI, Egidio. Il problema del corpo in S. Agostino. Roma: Edizioni Borba, 1989. 230 p.

MESSINA, Giuseppe. Il Manicheismo. In: VENTURI, Pietro Tacchi (Org.). Storia delle religioni. Torino: Unione Tipografico/Editrice Torinese, 1954. p. 291-302.

PIERETTI, Antonio. Sant'Agostino: sessualità e amore - il dono reciproco nel matrimonio. Roma: Città Nuova Editrice, 1996. 156 p.

PUECH, Henri-Charles. Sul manicheismo e altri saggi. Trad. di Augusto Combra. Torino: Giulio Einaudi Editore, 1995. 463 p.

Manichéisme In: Enciclopaedia Universalis. Paris: Enciclopaedia Universalis France, 1990. Corpus 14, p. 436-446. 
RANKE-HEINEMANN, Uta. Eunucos pelo reino de Deus: mulheres, sexualidade e a Igreja Católica. Trad. de Paulo Fróes. Rio de Janeiro: Record/Rosa dos tempos, 1996. 383 p.

TRAPE, Agostino. S. Agostino: l' uomo, il pastore, il mistico. Fossano: Editrice Esperienze, 1976. $439 \mathrm{p}$.

VANNINI, Marco. Invito al pensiero di sant'Agostino. Milano: Mursia Editore, 1989. 200 p. 